\title{
DETERMINING THE WATER QUALITY INDEX OF TREATED WASTE WATER FOR REPELLENT AND WETTABLE SANDY LOAM BASED ON INFILTRATION CHARACTERISTICS
}

\author{
ZHAO, X. ${ }^{1 \mathrm{~A}}-$ CHAI, H. Y. $.^{1,2 \mathrm{~A}}-$ CAI, Y. H. ${ }^{1}-$ CHEN, J. Y. $.^{*}-$ WU, P. T. ${ }^{1}-$ LI, Y. ${ }^{1}-$ CHEN, H. Y. ${ }^{3}$ \\ ${ }^{1}$ College of Water Resources and Architectural Engineering, Key Laboratory of Agricultural \\ Soil and Water Engineering in the Ministry of Education, Northwest A\&F University, Yangling, \\ Shaanxi 712100, China \\ ${ }^{2}$ Northwest Research Institute of Engineering Investigations and Design, Xi'an, Shaanxi \\ 710000, China \\ ${ }^{3}$ Department of Foreign Languages, Northwest A\&F University, Yangling, Shaanxi 712100, \\ China \\ ${ }^{A}$ These authors contributed equally to this work. \\ "Corresponding author \\ e-mail: cjyrose@126.com \\ (Received $10^{\text {th }}$ Dec 2019; accepted 24 ${ }^{\text {th }}$ Mar 2020)
}

\begin{abstract}
Treated waste water (TWW) has been replacing fresh water (FW) partly in irrigation. However, irrigation with TWW can cause soil water repellency that affects infiltration characteristics. In order to determine the water quality index with full consideration taken into infiltration characteristics, one dimensional infiltration experiments were conducted in wettable and repellent sandy loams with TWW irrigation. Five kinds of TWW and one tap water (TW) were chosen. The effect of water quality on the wetting front and cumulative infiltration volume was analyzed. The comprehensive water quality index (ZF) was obtained by principal component analysis. The results show that the water quality has a great effect on the cumulative infiltration and wetting front of wettable soil. The more significant the comprehensive water quality index is, the greater the cumulative infiltration volume and wetting front are. The water quality has a great effect on the cumulative infiltration and no effect on wetting front of repellency soil. Power correlation exists between sorptivety (S) and chemical oxygen demand (COD). Meanwhile, a quadratic polynomial relationship exists between the ratio of $\mathrm{S}$ for the wetting front coefficient and $\mathrm{ZF}$, and there is a minimum value in the curve.
\end{abstract}

Keywords: soil water repellency, soil moisture, wetting front, cumulative infiltration, COD

\section{Introduction}

Treated waste water (TWW) irrigation has become a common practice in arid and semiarid areas to deal with water scarcity and reduce the consumption of fresh water (FW) (Wallach et al., 2005). However, such irrigation may have an impact on the chemical and hydraulic properties of soils. Long-term TWW irrigation will increase soil organic matter $(\mathrm{OM})$ and form a layer of hydrophobic organic compounds on the surface of soil particles (Chen et al., 2009; Nadav et al., 2012a, 2012b), which will cause soil water repellency. The water drop penetration time (WDPT) of repellent soils could reach $802 \mathrm{~s}$ for sandy soils (Mataix-Solera et al., 2011) and $3600 \mathrm{~s}$ in clay loam with long-term TWW irrigation (Wallach et al., 2005). The occurrence of water repellency leads to a decrease of soil infiltration rate and water conductivity, which affects irrigation efficiency (Wallach et al., 2005; Leuther et al., 2018). 
The reduction of irrigation efficiency is shown in the decrease of the infiltration rate and the migration rate of wetting front which becomes irregular and unstable during irrigation process. Rye and Smettem (2017) found water repellency reduced the rate of water migration and the evaporation of soil surface water. It is easy to form a preferential flow in repellency soil due to the big difference in the movement of water in horizontal and gravitational directions (DeBano, 2000; Wallach et al., 2008, 2010). The water tends to accumulate on the surface of repellent soil (DeBano, 2000) and cannot infiltrate when the depth of water accumulation is less than the matrix suction of the soil during irrigation (Jordán et al., 2009). However, the above researches mainly aim to obtain the discipline of water movement by FW irrigation in repellent soil. Irrigation water source seldom changes after the soil repellency appears for a long time of TWW irrigation. Therefore, it is very important to study the infiltration law of TWW in repellent soil.

TWW has many components such as grease, OM, suspended solids, salt and so forth (Halliwell et al., 2001). Each component will affect the characteristics of the soil, and then change its infiltration characteristics during the infiltration. Suspended particulate matter and dissolved organic matter (DOM) can clog the soil pores (Vries, 1972; Vinten et al., 1983; Levy et al., 1999). High concentration of sodium ions causes swelling and dispersion of soil clay (Durgin et al., 1984; Frenkel et al., 1992; Levy et al., 1999; Halliwell et al., 2001). Inorganic salt increases the alkalinity and salinity of the soil (Balks et al., 1998; Halliwell et al., 2001; Lado et al., 2009; Bedbabis et al., 2014). These components reduce the pores of the soil, the hydraulic conductivity of the soil and the cumulative infiltration volume. However, some components of TWW can increase soil infiltration in repellent soils. Surfactants alleviates the repellency degree of the soil which increases the cumulative infiltration after a long period of TWW irrigation (Chaney et al., 1986; Fortun et al., 1989; Piccolo et al., 1997; Dekker et al., 2018; Liu et al., 2019). Both characters of irrigated soil and irrigation water quality have great effect on soil water infiltration, and they are always interacting, continuous development and evolution (Sheng et al., 2016). Therefore, selection of right water quality index for different soils is of great significance in irrigation with TWW.

The water quality indexes standards, including biochemical oxygen demand (BOD), chemical oxygen demand (COD), suspended solids, anionic surfactants, $\mathrm{pH}$, total salt, chloride, sulfide, heavy metal content, fecal coliforms, aphid eggs, and so on, have been established for agricultural irrigation all over the world. However, these water quality indexes standards have taken the ecological environmental protection into account, but the impact of irrigation water quality on infiltration characteristics is not considered. There is no uniform comprehensive index, so it is applicative to find a comprehensive water quality index to guild TWW irrigation. The objective of this study was to determining the water quality index of TWW for repellent sandy loam (R) and wettable sandy loam (W) based on irrigation infiltration characteristics.

\section{Materials and Methods}

\section{Soil sampling and pretreatment}

The soil depth of $0 \sim 5 \mathrm{~cm}$ shows a certain degree water repellency after long-term TWW irrigation (Wallach et al., 2005; Mataix-Solera et al., 2011). Soil water repellency is not obvious below the depth of $5 \mathrm{~cm}$. The soil samples were collected in $0 \sim 5 \mathrm{~cm}$ surface sandy loam in the first terrace of Wei River, Yangling $\left(34^{\circ} 18^{\prime} \mathrm{N}, 108^{\circ} 24^{\prime} \mathrm{E}\right)$, Shaanxi Province, China. The bulk density, grain-size distribution of the soil was measured by the drying 
method and Mastersizer 2000 laser particle size analyzer in the laboratory, respectively. The soil, whose bulk density is $1.65 \mathrm{~g} / \mathrm{cm}^{3}$, is composed of $14.4 \%$ of clay, $24.7 \%$ of silt and $60.9 \%$ of sand. Therefore, the soil texture is identified as wettable sandy loam. The soil, after air-drying and impurity removal, was subjected to standard sieving of 10-mesh (2 $\mathrm{mm})$. The soil moisture after air drying and saturated soil moisture were $0.029 \mathrm{~cm}^{3} / \mathrm{cm}^{3}$ and $0.363 \mathrm{~cm}^{3} / \mathrm{cm}^{3}$, respectively.

The field water-repellent soil is prone to disturbance in the sampling, which may destroy its original water-repellent characteristics. Therefore, surface active material, octadecylamine $\left(\mathrm{C}_{18} \mathrm{H}_{39} \mathrm{~N}\right)$, is added to wettable soil to obtain a relatively stable waterrepellent soil (J\&K Scientific Ltd.). Octadecylamine, a white waxy solid crystal with alkalinity, is practically insoluble in water. Its melting point is $52.3^{\circ} \mathrm{C}$. The repellency soil was obtained by mixing $\mathrm{C}_{18} \mathrm{H}_{39} \mathrm{~N}$ with the air-dried soil sample at a ratio of $0.1 \mathrm{~g} / \mathrm{kg}$. Then the mixed soil was placed in an oven at $80^{\circ} \mathrm{C}$ for 24 hours, and the soil sample was stirred for 5 minutes every 2 hours to make the liquid $\mathrm{C}_{18} \mathrm{H}_{39} \mathrm{~N}$ fully mixed with the soil particles (Li et al., 2017). This approach eliminated the confounding time effects associated with unstable water repellency systems and allowed for the identification of basic mechanisms (Carrillo et al., 2000). The relatively stable water-repellent sandy loam was obtained after the whole process. The repellency was determined by water drop penetration time test (WDPT) (Letey, 1969; Dekker et al., 1990). According to the water repellency classification standard proposed the mixed soil is slightly water repellent (Bisdom et al., 1993).

\section{Water sampling and water quality index}

The TWW sample was taken from pools under different treatments, namely the catchment, the anaerobic pool, the oxidation pool, the sedimentation pool and the outlet pool, in a domestic sewage treatment plant in China. The reference water is tap water in Yangling, China. The water quality index is given in Table 1.

Table 1. Water quality index of TW and pools under different treatment

\begin{tabular}{c|c|c|c|c|c|c}
\hline The location of the water & Tap water & Catchment & $\begin{array}{c}\text { Anaerobic } \\
\text { pool }\end{array}$ & $\begin{array}{c}\text { Oxidation } \\
\text { pool }\end{array}$ & $\begin{array}{c}\text { Sedimentation } \\
\text { pool }\end{array}$ & $\begin{array}{c}\text { Outlet } \\
\text { pool }\end{array}$ \\
\hline $\mathrm{pH}$ & 7.92 & 7.29 & 7.31 & 7.31 & 7.36 & 7.07 \\
Electric conductivity $\left(\mu \mathrm{S} \cdot \mathrm{cm}^{-1}\right)$ & 143 & 811 & 825 & 811 & 849 & 799 \\
Dissolved oxygen $\left(\mathrm{mg} \cdot \mathrm{L}^{-1}\right)$ & 7.52 & 0.24 & 0.43 & 3.00 & 4.61 & 4.03 \\
Total hardness $\left(\mathrm{mmol} \cdot \mathrm{L}^{-1}\right.$ ) & 0.89 & 0.49 & 0.64 & 0.61 & 0.68 & 0.79 \\
Total alkalinity $\left(\mathrm{CaO} \mathrm{mg} \cdot \mathrm{L}^{-1}\right)$ & 27.96 & 169.81 & 176.32 & 164.37 & 167.67 & 153.21 \\
Sodium adsorption ratio a & 1.23 & 6.12 & 6.16 & 6.98 & 6.77 & 7.01 \\
Turbidity & 0 & 125 & 187 & 510 & 4.77 & 3.95 \\
Total dissolved substances $\left(\mathrm{mg} \cdot \mathrm{L}^{-1}\right)$ & 95 & 226 & 360 & 260 & 412 & 420 \\
Total suspended solids $\left(\mathrm{mg} \cdot \mathrm{L}^{-1}\right)$ & 0 & 170 & 198 & 780 & 325 & 242 \\
Total nitrogen $\left(\mathrm{mg} \cdot \mathrm{L}^{-1}\right)$ & 18.23 & 69.27 & 100.3 & 63.83 & 36.22 & 30.12 \\
Chemical oxygen demand $\left(\mathrm{mg} \cdot \mathrm{L}^{-1}\right)$ & 0 & 331.5 & 423 & 588 & 37.15 & 22.15 \\
Biochemical oxygen demand & 0 & 171 & 100 & 143 & 11 & 11 \\
(mg $\cdot \mathrm{L}^{-1}$ ) & 0 & &
\end{tabular}

a. The sodium adsorption ratio (SAR) refers to the ratio of the sodium ion concentration to the square root of the mean value of the calcium ion concentration and the magnesium ion concentration in the cation exchange reaction of calcium, magnesium, sodium, etc. The formula of the sodium adsorption ratio is SAR $=\frac{C_{\left(\mathrm{Na}^{+}\right)}}{\sqrt{C_{\left(\mathrm{Ca}^{2+}\right)}+C_{\left(\mathrm{Mg}^{2+}\right)}}}($ Bughici and Wallach, 2016), where, the values are expressed in $\operatorname{mmol} \cdot 1^{-1}$ 
There are 12 water quality parameters, including $\mathrm{pH}$, Electric conductivity, dissolved oxygen, total hardness, total alkalinity, sodium adsorption ratio (SAR), turbidity, total dissolved substances (TDS), total suspended solids (TTS), total nitrogen (TN), Chemical oxygen demand (COD) and Biochemical oxygen demand (BOD). Principal component analysis was conducted on each water quality index using SPSS software (v. 21.0, SPSS Inc, 2013) in order to quantitatively evaluate the water quality. First, three principal components are extracted, and then the water quality comprehensive evaluation index is established according to the contribution rate of the characteristic value of each principal component in initial eigenvalues Eq.l.

The formula for the comprehensive index of water quality is as follows.

$$
\mathrm{Z}_{F}=\frac{\lambda_{1}}{\lambda_{1}+\lambda_{2}+\lambda_{3}} \cdot F_{1}+\frac{\lambda_{2}}{\lambda_{1}+\lambda_{2}+\lambda_{3}} \cdot F_{2}+\frac{\lambda_{3}}{\lambda_{1}+\lambda_{2}+\lambda_{3}} \cdot F_{3}
$$

where $\lambda_{1}, \lambda_{2}$ and $\lambda_{3}$ are eigenvalues of the first, second and third principal components, respectively. $F_{1}, F_{2}$ and $F_{3}$ are the calculated values of the three components, respectively.

\section{Infiltration experiments}

The infiltration experiments were carried out in Key Laboratory of Agricultural Soil and Water Engineering in Arid and Semiarid Areas, Ministry of Education, Northwest A\&F University, China.

Two kinds of soils (wettable soil and repellency soil) were irrigated by six kinds of water with different quality in one-dimensional water infiltration experiments. The experiments consisted of 12 treatments, and each treatment was repeated 3 times. For convience, in the rest part of the paper, $\mathrm{R}$ and $\mathrm{W}$ are repellent sandy loam and wettable sandy loam, respectively; R-TW and R-TWW1 5 refer to the six water quality experiment waters that are ranked according to the comprehensive water quality index from small to large. Among them, TW is tap water, R-TWW1 is the water from outlet pool, R-TWW 2 $\sim 5$ are waters from sedimentation pool, catchment, anaerobic pool and oxidation pool, the same below.

The experiment device is shown in Fig. 1. The water supply device is a Marriotte bottle to provide a stable water head. The column is $80 \mathrm{~cm}$ in height $12 \mathrm{~cm}$ in diameter. The bottom of the column is equipped with a $10 \mathrm{~cm}$ of quartz sand filter layer to prevent air resistance. The soil sample is loaded into the soil column according to the actual bulk density of $1.65 \mathrm{~g} / \mathrm{cm}^{3}$. The soil is layered into the soil column and each layer is 5 $\mathrm{cm}$. The layers were slightly roughened to prevent delamination. The soil column is 65 $\mathrm{cm}$ in height. The soil columns were placed for 24 hours after loading to make the soil moisture distribute evenly. A filter paper is placed on the surface of the soil column to resist the impact of water on the soil. Three paper scales are placed on the column to record wetting front. The water head is $3 \mathrm{~cm}$ in the experiments. The infiltration time was recorded using the stopwatch. During the first half hour of the experiments, the Mariotte scale and the wetting front were recorded at 5-min intervals. Subsequently they were recorded at intervals of 10 -min from $0.5 \mathrm{~h}$ to $1.5 \mathrm{~h}$, and 30 -min after $1.5 \mathrm{~h}$.

The Philip model (Philip, 1957) was used to fit the soil cumulative infiltration with time to further analyze the effect of water quality on soil infiltration. The mathematical expression of the model is as follows. 


$$
I=S t^{0.5}+A t
$$

where, $I$ is the cumulative infiltration, $\mathrm{cm} ; S$ is the soil sorptivety, $\mathrm{cm} \cdot \mathrm{min}^{-0.5} ; A$ is the stable infiltration rate, $\mathrm{cm} / \mathrm{min}$; $t$ is the infiltration time, $\mathrm{min}$.
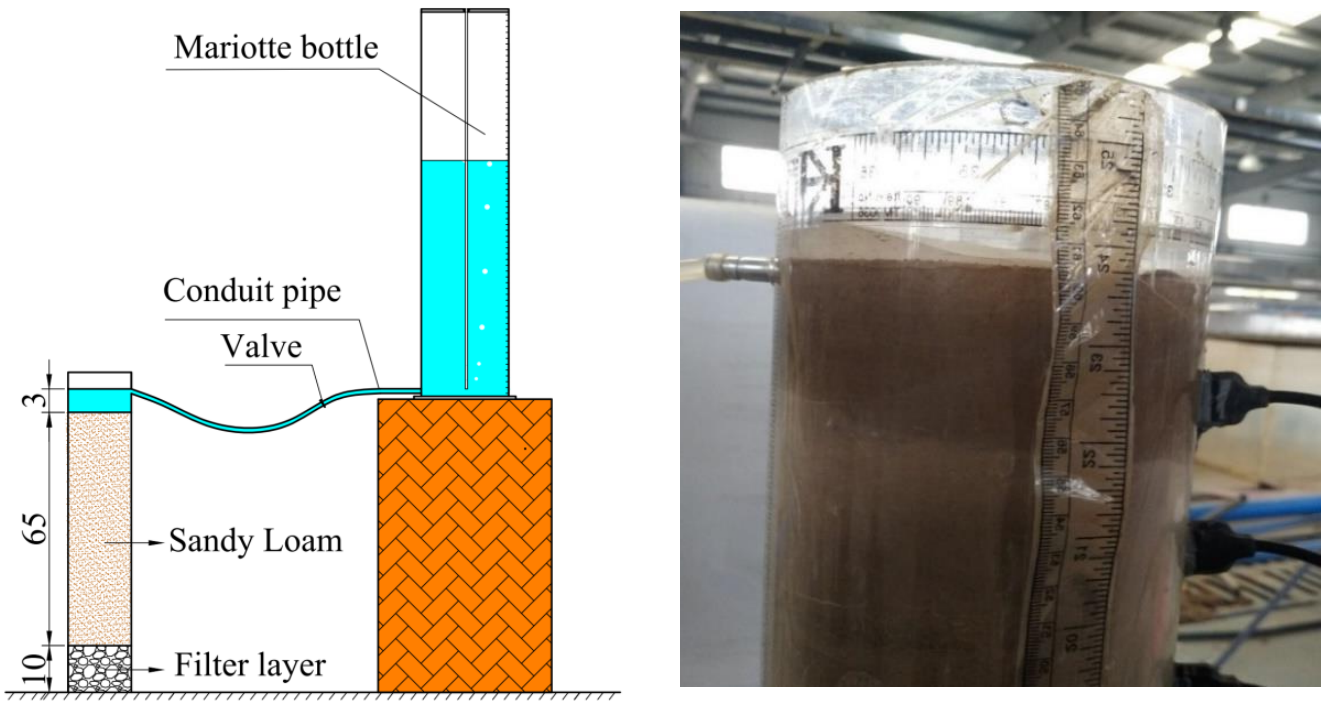

Figure 1. Laboratory setup of one-dimensional TWW infiltration

When the infiltration time of the experiment is as short as a couple of hours, the soil sorptivety $(S)$ becomes the main influencing factor of water infiltration. That is, the effect of the stable infiltration rate $A$ can be neglected. Then the Eq.2 can be expressed as follows.

$$
I=S t^{0.5}
$$

Then this paper uses the Eq.3 to fit the cumulative infiltration and time.

In this study, SPSS 22.0 was used to conduct analysis of variance between means, and significant differences between the treatments were compared by the least significant differences test at a 5\% probability, orthogonal design, Standard analysis of variance (ANOVAR) were used to evaluate the effect of the water quality on the infiltration.

\section{Results and Discussion}

\section{Comprehensive evaluation result of water quality}

Three principal components were extracted using principal component analysis of SPSS. The first principal component eigenvalue has the highest contribution rate of $38.35 \%$. Total dissolved substances, sodium adsorption ratio and conductivity are the main factors of water quality index of the first principal component. The contribution rate of the second principal component eigenvalue is $35.89 \%$. BOD, COD, the total dissolved oxygen, total nitrogen and total hardness are the main factors of the second main component. The total suspended matter and turbidity take up a larger proportion of the third principal component. The cumulative contribution rate of the three principal 
components eigenvalue reaches $95.21 \%$, which can basically represent the information of all 12 water quality indexes. A comprehensive evaluation index is established according to the contribution rate of the eigenvalues as is shown in Eq.4.

$$
\mathrm{Z}_{\mathrm{F}}=40.29 \% \cdot F_{1}+37.70 \% \cdot F_{2}+22.02 \% \cdot F_{3}
$$

The comprehensive evaluation result of water quality is given in Table 2 .

Table 2. Principal component analysis results, the water quality comprehensive index and the naming of water samples

\begin{tabular}{c|c|c|c|c|c}
\hline $\begin{array}{c}\text { Water sampling } \\
\text { location }\end{array}$ & $\begin{array}{c}\text { First principal } \\
\text { component } \boldsymbol{F}_{\mathbf{1}}\end{array}$ & $\begin{array}{c}\text { Second principal } \\
\text { component } \boldsymbol{F}_{\mathbf{2}}\end{array}$ & $\begin{array}{c}\text { Third principal } \\
\text { component } \boldsymbol{F}_{\mathbf{3}}\end{array}$ & $\begin{array}{c}\text { The water quality } \\
\text { comprehensive } \\
\text { index } \boldsymbol{Z}_{\boldsymbol{F}}\end{array}$ & $\begin{array}{c}\text { Levels of } \\
\text { TWW }\end{array}$ \\
\hline Tap water & -1.812 & -0.834 & -0.415 & -1.136 & $\mathrm{TW}$ \\
Catchment & -0.133 & 1.372 & -0.557 & 0.341 & $\mathrm{TWW} 3$ \\
Anaerobic pool & 0.197 & 1.007 & -0.388 & 0.374 & $\mathrm{TWW} 4$ \\
Oxidation pool & -0.063 & 0.117 & 2.032 & 0.466 & TWW 5 \\
Sedimentation pool & 0.809 & -0.748 & -0.265 & -0.014 & TWW 2 \\
Outlet pool & 1.002 & -0.914 & -0.407 & -0.030 & TWW1 \\
\hline
\end{tabular}

According to the water quality comprehensive index, the irrigation waters taken from different locations in the domestic sewage treatment plant are ranked from small to large of $Z_{F}$. The comprehensive water quality index of the outlet pool is the smallest, and the oxidation pond outlet is the largest. That might be because TWW needs to add biological bacteria such as nitrates for denitrification and absorption of easily degraded BOD before treated in the oxidation pond. After entering the sedimentation pond, mud and water are separated under the effect of coagulant drugs, and the water quality is greatly improved. For the convenience of the following description, TW represents tap water, TWW1, TWW2, TWW3, TWW4 and TWW5 represent the water of the outlet pool, sedimentation pool, catchment, anaerobic pool and oxidation pool respectively.

\section{Effect of water quality on cumulative infiltration}

The variation of cumulative infiltration of wettable and repellent sandy loams under different water infiltration conditions are shown in Fig. 2. The cumulative infiltration of different water quality in wettable sandy loam is significant ( $\mathrm{P}$ value<0.05) (Fig. 2a). The cumulative infiltration amount increases with the increase of water quality comprehensive index. That is, the greater the comprehensive water quality index is, the faster the infiltration in wettable soil is. Taking $90 \mathrm{~min}$ as an example, the cumulative infiltration amounts of W-TW and W-TWW1 5 are 7.19, 13.13, 13.70, 15.48, 17.18 and $16.02 \mathrm{~cm}$, respectively. When the wetting front reaches the end of $40 \mathrm{~cm}$ infiltration, the cumulative infiltration amount is $12.65,17.3,17.18,18.19,19.96$ and $18.21 \mathrm{~cm}$, respectively.

There is a significant difference between TWW and TW during the infiltration of waterrepellent sandy loam (Fig. 2b). However, the difference among the five groups of TWW is significantly reduced relative to the wettable sandy loam. Taking $90 \mathrm{~min}$ as an example, the cumulative infiltration of R-TW and R-TWW1 5 is 6.17, 11.58, 11.74, 12.06, 15.53 and $13.15 \mathrm{~cm}$, respectively. The cumulative infiltration of R-TW and R-TWW1 5 was 10.50, $16.85,17.36,17.68,19.84$ and $17.88 \mathrm{~cm}$, respectively at the end of infiltration. Comparing 
Fig. $2 a$ and Fig. $2 b$, it is found that the cumulative infiltration in the water-repellent soil is smaller than that in the wettable soil with the same water quality. Taking W-TWW3 and RTWW3 as examples, the cumulative infiltration of W-TWW3 is $13.70 \mathrm{~cm}$ and the RTWW3 is $11.73 \mathrm{~cm}$ at $90 \mathrm{~min}$. Therefore, it can be inferred that regardless of tap water or sewage water, the water-repellent soil will hinder its water migration and affect its infiltration rate.

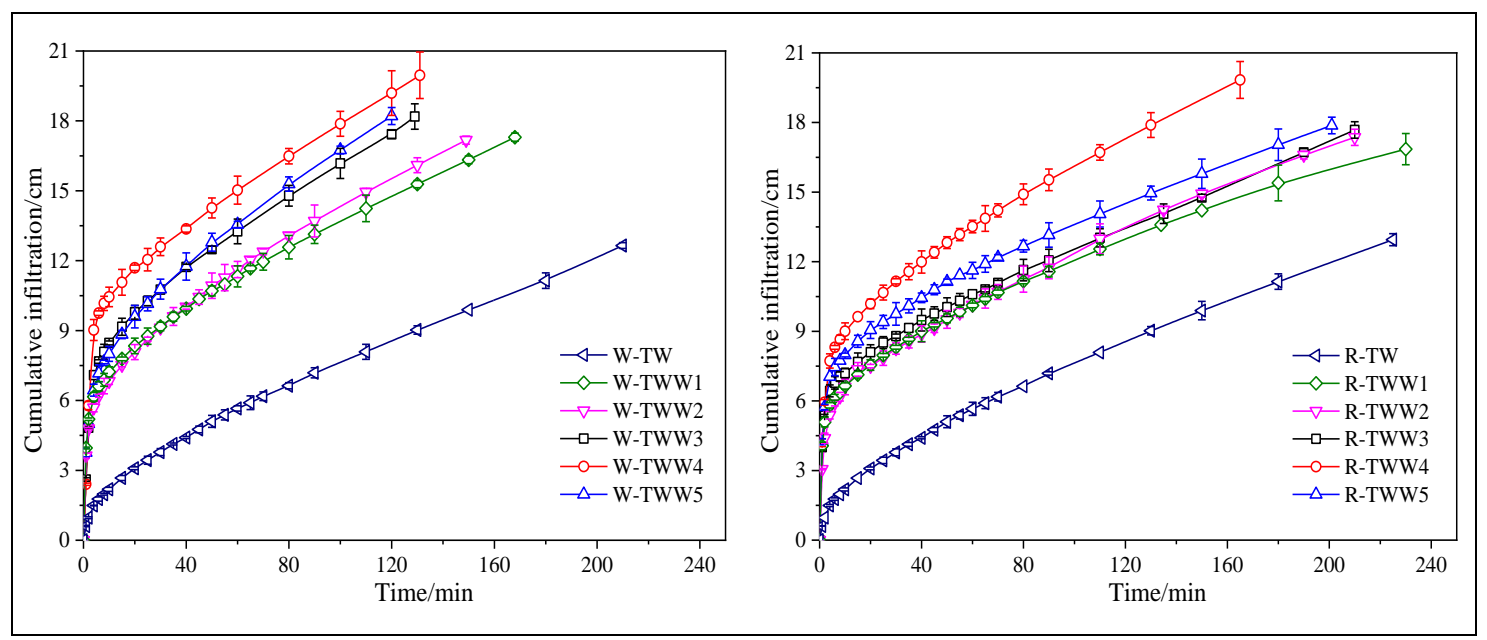

Figure 2. The cumulative infiltration versus time for different water quality in repellent and wettable sandy loams, (a) Wettable sandy loam, (b) Repellent sandy loam

Table 3 shows the relationship between the cumulative infiltration and time. The fitting accuracy of the Philip model of TWW infiltration is worse than that of tap water, but the coefficient of determination is greater than 0.7 and the root mean square error is small. Therefore, the curves fit well with the data with high Determination coefficient $\left(R^{2}>0.988\right)$. There is a positive correlation between the infiltration rate and water quality (water from TW, TWW1 to TWW5) of wettable and repellent sandy loams. The infiltration rate of the wettable soil is higher than that of the water-repellent soil with the same kind of water. The regularity of the infiltration rate is the same as the law of cumulative infiltration.

Table 3. The fitting parameters of the infiltration model

\begin{tabular}{|c|c|c|c|c|c|c|c|}
\hline \multirow[b]{2}{*}{ Soil type } & \multirow[b]{2}{*}{ Treatment } & \multicolumn{3}{|c|}{ Philip formula } & \multicolumn{3}{|c|}{$\begin{array}{l}\text { Wetting front model } \\
\end{array}$} \\
\hline & & $\begin{array}{l}\text { Sorptivety } S \\
\left(\mathrm{~cm} \cdot \mathrm{min}^{-0.5}\right)\end{array}$ & $\begin{array}{c}\text { Determination } \\
\text { coefficient } R^{2}\end{array}$ & \begin{tabular}{|c|} 
Root mean \\
square error \\
RMSE \\
\end{tabular} & $\begin{array}{c}\text { Fitting } \\
\text { parameter } a \\
\left(\mathrm{~cm} \cdot \mathrm{min}^{-0.5}\right)\end{array}$ & \begin{tabular}{|c|} 
Determination \\
coefficient \\
$\boldsymbol{R}^{\mathbf{2}}$ \\
\end{tabular} & $\begin{array}{c}\text { Root mean } \\
\text { square error } \\
\text { RMSE } \\
\end{array}$ \\
\hline \multirow{6}{*}{$\begin{array}{c}\text { Wettable } \\
\text { sandy } \\
\text { loam }\end{array}$} & W-TW & 0.776 & 0.982 & \begin{tabular}{l|}
0.450 \\
\end{tabular} & 2.652 & \begin{tabular}{|l|}
0.990 \\
\end{tabular} & 0.342 \\
\hline & W-TWW1 & 1.463 & 0.809 & 1.700 & 2.982 & 0.994 & 0.912 \\
\hline & W-TWW2 & 1.522 & 0.880 & 1.385 & 3.192 & 0.993 & 0.895 \\
\hline & W-TWW3 & 1.769 & 0.825 & 1.985 & 3.394 & 0.997 & 0.980 \\
\hline & W-TWW4 & 2.002 & 0.701 & 2.825 & 3.347 & 0.995 & 0.907 \\
\hline & W-TWW5 & 1.837 & 0.862 & 1.707 & 3.618 & 0.995 & 1.218 \\
\hline \multirow{6}{*}{$\begin{array}{c}\text { Repellent } \\
\text { sandy } \\
\text { loam }\end{array}$} & R-TW & 0.648 & 0.971 & 0.426 & 2.593 & 0.988 & 1.234 \\
\hline & R-TWW1 & 1.268 & 0.759 & 1.775 & 2.692 & 0.995 & 1.161 \\
\hline & R-TWW 2 & 1.299 & 0.860 & 1.476 & 2.590 & 0.993 & 0.691 \\
\hline & R-TWW 3 & 1.338 & 0.737 & 1.933 & 2.530 & 0.990 & 1.032 \\
\hline & R-TWW 4 & 1.695 & 0.721 & 2.202 & 2.950 & 0.990 & 0.888 \\
\hline & R-TWW 5 & 1.449 & 0.710 & 2.231 & 2.710 & 0.998 & 1.406 \\
\hline
\end{tabular}




\section{Effect of water quality on wetting front movement}

The wetting front depth versus time for different water quality in wettable and repellent sandy loams is shown in Fig. 3. The variation of the wetting front depth is similar to that of cumulative infiltration in wettable sandy loam (Fig. 3a). When different water infiltrates the wettable sandy loam, the greater the comprehensive water quality index is, the greater the depth of the wetting front is at the same infiltration time. The infiltration times of W-TW and W-TWW1 5 are 210, 168, 149, 129, 131 and 120 min, respectively, when the wetting front depth reaches $40 \mathrm{~cm}$ in wettable sandy loam. The water quality has little effect on the wetting front depth of repellent sandy loam (Fig. 3b). The infiltration times of R-TW and R-TWW1 5 are 210, 168, 149, 129, 131 and $120 \mathrm{~min}$, respectively, when the wetting front depth reaches $40 \mathrm{~cm}$ in repellent sandy loam. There is no significance difference between infiltration time and wetting front depth among the different irrigation water quality from TW, TWW1 to TWW5 in repellent sandy loam $(P>0.05)$. The wetting front depth of the water-repellent sandy loam is smaller than that of the wettable sandy loam with the same water quality (Fig. $3 a$ and Fig. 3b). The infiltration time of the water-repellent sandy loam is greater than that of the wettable sandy loam when the wetting front depth reaches $40 \mathrm{~cm}$.

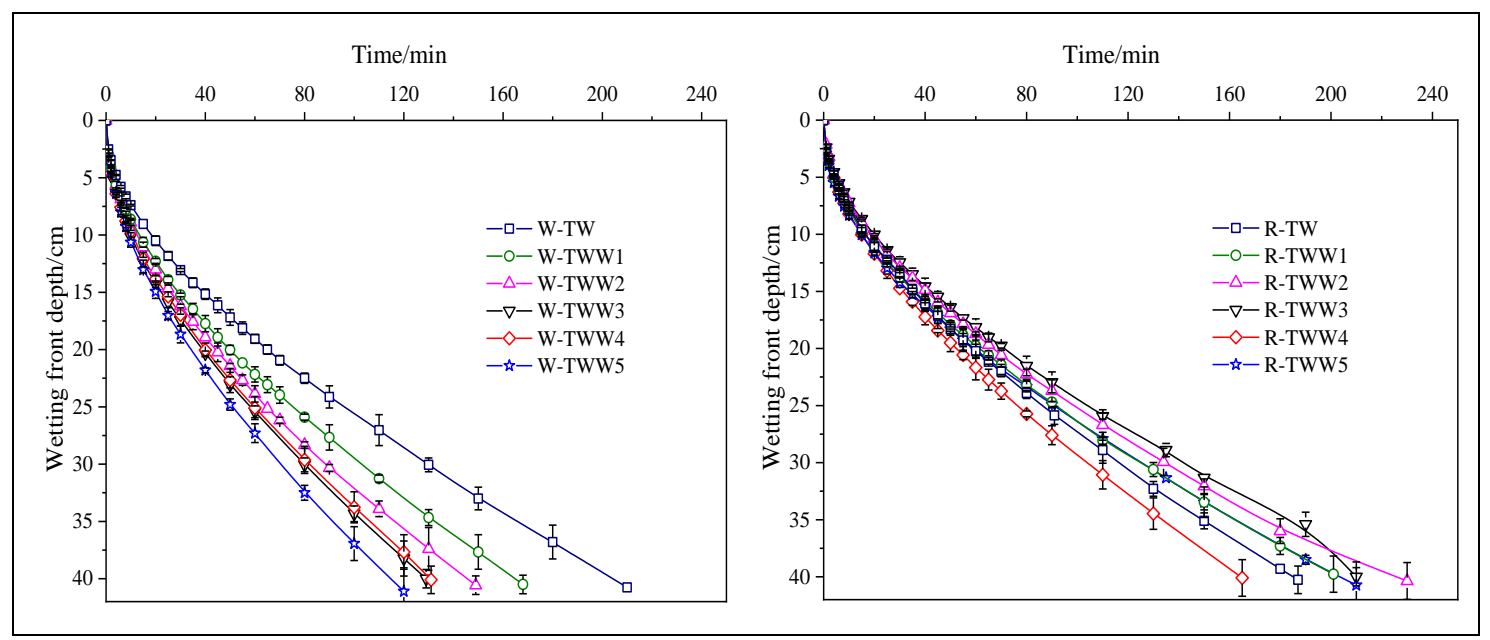

Figure 3. Wetting front depth versus time for different water quality in wettable and repellent sandy loams, (a). Wettable sandy loam, (b) Repellent sandy loa

The power function is used to fit the relationship between wetting front depth and infiltration time to analyze the effect of water quality on the soil wetting front. The mathematical expression of the model is as follows:

$$
H=a t^{0.5}
$$

where $H$ is wetting front depth, $\mathrm{cm} ; a$ is the wetting front coefficient, $\mathrm{cm} \cdot \mathrm{min}^{-0.5}$.

The wetting front model fitting result is given in Table 3. The fitting accuracy of the wetting front model $\left(R^{2}>0.98\right.$, RMSE $\left.<1.3\right)$ is high. Water quality has little effect on $a$ in repellent sandy loam. The parameter $a$ increases with the increase of the comprehensive water quality index in wettable sandy loam. 
The effect of irrigation water quality on the infiltration is significant (Fig. 2 and Fig. 3). The cumulative infiltration and infiltration rates generally increase with the increase of water quality comprehensive index.

The sorptivety of repellent sandy loam is smaller than that of wettable sandy loam with the same water (Table 3). According to the comprehensive water quality index from small to large (TW and TWW1 5), sorptivety decreases by 16.5\%, 13.3\%, 14.7\%, $24.4 \%, 15.3 \%$ and $21.1 \%$, respectively.

The effect of irrigation water quality on infiltration is mainly reflected in the influence of soil solute potential which is closely related to the conductivity in the water quality index. The higher the conductivity is, the greater the soil solute potential is, and the more obvious effect the water has on soil water movement. The electric conductivity value of TW is smaller than TWW (Table 1). Therefore, the cumulative infiltration of TWW is larger than that of TW irrigation. The cumulative infiltration shows little difference among the TWW due to the small difference in conductivity among them. It also shows the larger the conductivity is, the greater the cumulative infiltration is. The wetting front depth decreases with the increase of water quality comprehensive index in wettable sandy loam due to the large difference of solute potential. The solute potential is different because TWW contains many solute ions. The wetting front changes greatly with the same cumulative infiltration due to the different solute potential under the same condition of the matrix potential and the gravitational potential.

The water quality comprehensive index has no significant effect on the wetting front in repellent sandy loam because water repellency seriously hinders the water infiltration. So the solute potential caused by the substances contained is smaller than that of the water repellency of both TW and TWW in repellent soil. Therefore, the wetting front has no significance among TW and TWW1 5.

TWW contains many components. It's insufficient to use a single water quality index to analyze the effect of infiltration. For example, the total suspended matter in the water quality index describes the amount of insoluble matter in the water. The suspended matter will deposit on the surface layer or block the soil pores which make the soil surface crust and soil porosity reduction during the infiltration process. Then the soil infiltration rate and the hydraulic conductivity are significantly reduced. It is one of the causes of soil water repellency. However, the effect of suspended matter in TWW on soil pores during the short-term infiltration is not obvious due to the short experiments period in this study. The clogging is weak because of the large particles and soil pores in sandy loam. Soil infiltration rate and hydraulic conductivity decline significantly because the clogging, caused by sewage or TWW irrigation in soils with higher clay content, is obvious (Lado and Ben-Hur, 2009). Therefore, the suspended matter is an important index for long-term irrigation with TWW.

The water movement rate is high in the irrigation of wettable soil with the TWW. The irrigation time must be shortened when the irrigation volume is fixed, or it will cause deep leakage. The TWW contains more polluting ions which may cause groundwater pollution and soil nutrients loss (Lado and Ben-Hur, 2009). However, wetting front is of no difference under the same irrigation time interval in the irrigation of the repellent soil with the TWW. Then the greater the water quality index is, the greater the irrigation volume is. This will cause the water to stay in the upper layer of the soil for a long time, and it is difficult to reach the planned wetting layer of the irrigation design. At the same time, the evaporation of the surface layer increases, resulting in a decrease in water use efficiency. Therefore, the irrigation time should be 
reduced and high frequency and small flow discharge should be used in order to increase the effective irrigation depth for the soil for high water quality index in repellent soil.

\section{Effect of COD on infiltration parameters}

There are many causes of the water repellency in the soil (Bond, 1964; McGhie et al., 1980; King et al., 1981; DeBano, 1981; Jex et al., 1985; Stenstrom et al., 1989; Shakesby et al., 1993, 2006; Dekker et al., 2000; Chau et al., 2012; Jiménez-Pinilla et al., 2016). For sewage water irrigation, water repellency is caused by the increase of the organic matter in the soil (Morales et al., 2010; Chen et al., 2013). In the irrigation with TWW, the oil and grease content in the water has a great influence on the soil water repellency, and the soil water repellency increases with the increase of oil and grease (Travis et al., 2008). As the organic matter in the soil increases, the water repellency of sandy and clay increases. The organic matter in water is measured by COD value. During the infiltration, the organic matter and grease affect the surface tension of the liquid, which in turn affects the interaction between the soil particles and the water molecules. It will affect the capillary force during the movement of soil water. And these can be described by the COD value. The relationship between COD and sorptivety is shown in Fig. 4. The relationship between sorptivity $S$ and COD is a power function.

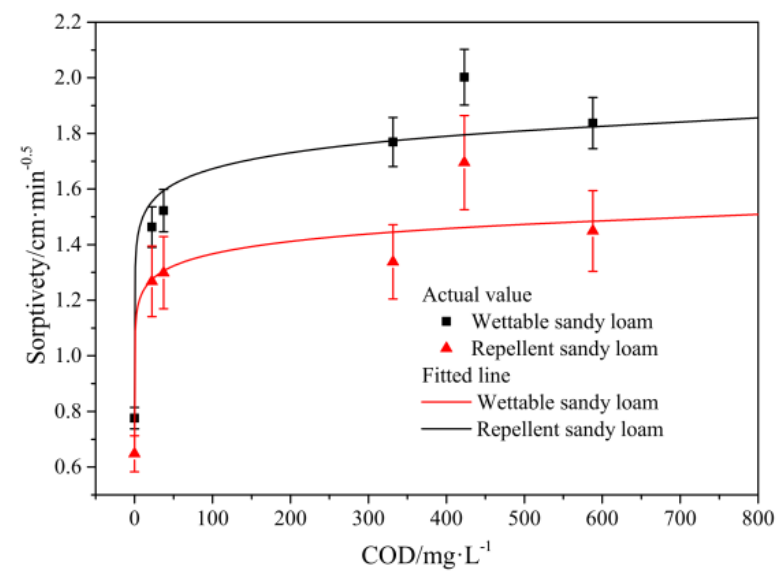

Figure 4. The relationship between the soil sorptivety $(S)$ and chemical oxygen demand (COD)

The function is as follows.

Wettable sandy loam:

$$
S_{w}=1.322 \cdot(\mathrm{COD})^{0.053}, R^{2}=0.931
$$

Repellent sandy loam:

$$
S_{r}=1.104 \cdot(C O D)^{0.046}, R^{2}=0.955
$$

The effect of COD on infiltration is obvious when COD is less than a certain value for wettable and repellent soils. When the COD exceeds the set value, the change of the infiltration rate is small although the COD has a large change. 
With the infiltration change rate of $0.05 \mathrm{~cm} / \mathrm{min} 0.5$ as the critical point, when the COD value of the irrigation water is greater than $170 \mathrm{mg} / \mathrm{L}$ for wettable sandy soil and $140 \mathrm{mg} / \mathrm{L}$ for repellent sandy soil, the COD has little effect on irrigation.

Therefore, the influence of COD on soil water infiltration must be considered. The Farmland Irrigation Water Quality Standard GB5084-2005 in China stipulates that the COD of irrigation water should be less than $200 \mathrm{mg} / \mathrm{L}$ for dry crop irrigation. According to this study, considering the effect of COD values on infiltration, we recommend that the COD value should be less than $170 \mathrm{mg} / \mathrm{L}$ for wettable sandy soil and $140 \mathrm{mg} / \mathrm{L}$ for repellent sandy soil in sewage irrigation.

\section{Effect of comprehensive water quality indicators on infiltration parameters}

The effect of water quality on infiltration can be seen from the above research. EC, TSS and COD all have an effect on infiltration. Previous studies focused on the impact of a water quality index on infiltration, but research shows that many water quality indexes affect soil infiltration (Singh et al., 2017; Misaghi et al., 2017; Leuther et al., 2018). Therefore, it is necessary to use comprehensive water quality indicators to analyze the impact of water quality on infiltration. The relationship between $Z_{F}$ and sorptivety $S$ was shown in Fig. $5 a$. The $S$ of sandy loam increases with the increase of $Z_{F}$, and there is a positive linear correlation between them $\left(R^{2}\right.$ is 0.980 and 0.950 for wettable and repellent sandy loams).

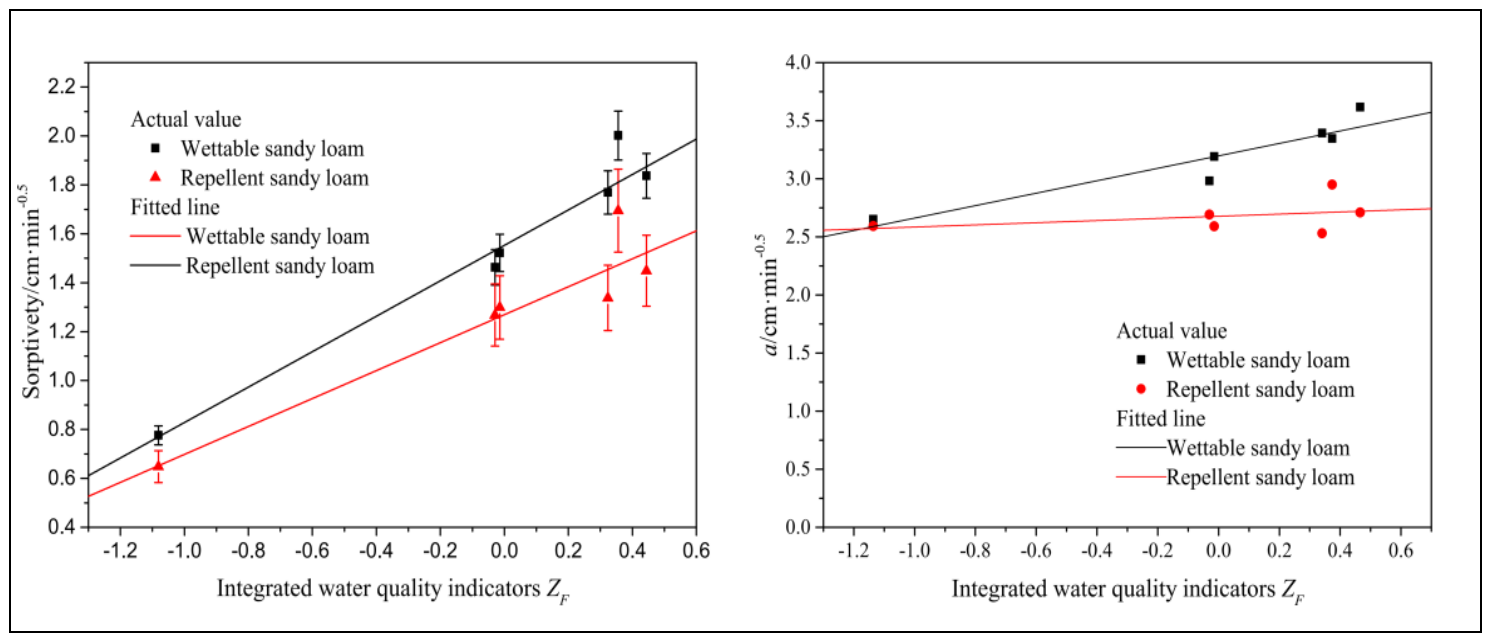

Figure 5. Relationships between soil sorptivety $(S)$, the wetting front coefficient $a$ and comprehensive water quality index $Z_{F}(a)$. soil sorptivety, $(b)$ the wetting front coefficient a

The function is as follows.

Wettable sandy loam:

$$
S_{\mathrm{w}}=1.553 \cdot Z_{F}+0.724, \quad R^{2}=0.980
$$

Repellent sandy loam:

$$
S_{r}=1.269 \cdot Z_{F}+0.571, \mathrm{R}^{2}=0.950
$$


It can be seen that the larger the comprehensive water quality index is, the faster sorptivety of the soil is (Eq.8, Eq.9, Fig. 5a). The quality of TWW significantly facilitates soil infiltration. However, soil water repellency will lead to a decrease in soil infiltration rate when water infiltrates, and also slow down the tendency of infiltration rate to increase with the increase of the comprehensive water quality index. Soil water repellency will decrease soil infiltration and also slow down the tendency of sorptivety to increase with the increase of ZF. For wettable soils, the water quality of TWW is more significant in increasing soil infiltration. The sorptivety of the wettable sandy loam is larger than that of the repellent sandy loam with the same water quality (Fig. 2 and Table 3). The effect of $\mathrm{ZF}$ on sorptivety of the wettable sandy loam is larger than that of the repellent sandy loam. Therefore, it is not advisable to increase the infiltration rate of the soil in order to reduce the irrigation time and simply increase the comprehensive water quality index. The selection of the comprehensive water quality index should be within a reasonable range.

It can be seen that the larger the comprehensive water quality index is, the faster sorptivety of the soil is (Eq.8, Eq.9, Fig. 5a). The quality of TWW significantly facilitates soil infiltration. However, soil water repellency will lead to a decrease in soil infiltration rate when water infiltrates, and also slow down the tendency of infiltration rate to increase with the increase of the comprehensive water quality index. Soil water repellency will decrease soil infiltration and also slow down the tendency of sorptivety to increase with the increase of $Z_{F}$. For wettable soils, the water quality of TWW is more significant in increasing soil infiltration. The sorptivety of the wettable sandy loam is larger than that of the repellent sandy loam with the same water quality (Fig. 2 and Table 3). The effect of $Z_{F}$ on sorptivety of the wettable sandy loam is larger than that of the repellent sandy loam. Therefore, it is not advisable to increase the infiltration rate of the soil in order to reduce the irrigation time and simply increase the comprehensive water quality index. The selection of the comprehensive water quality index should be within a reasonable range.

The relationship between the wetting front coefficient $a$ and $Z_{F}$ of the sandy loam is shown in Fig. 5b. The wetting front coefficient $a$ increases with the increase of $Z_{F}$, and there is a positive linear correlation between them for wettable sandy loam. However, $Z_{F}$ has little effect on the wetting front coefficient $a$ due to the effect of water repellency in repellent sandy loam.

The relationship between the ratio of sorptivety $S$ to the wetting front coefficient $a$ and $Z_{F}$ is shown in Fig. 6. There is a nonlinear relationship between $S / a$ and $Z_{F}$. As $Z_{F}$ increases, $S / a$ shows a minimum point. The minimum point appears near 0.59 and 0.10 for wettable and repellent sandy loams respectively. $S / a$ reflects the volume of water in the wetting body, i.e., the average increase in moisture content in the wetting front range. When $Z_{F}$ exceeds 0.10 for the water-repellent sandy loam, the increase of $S / a$ indicates that the wetting front coefficient is reduced with the same irrigation volume. That is to say, the increase of irrigation volume does not make the effective wetting depth increase significantly. Therefore, the value of $Z_{F}$ should be less than 0.10 of TWW when irrigating repellent sandy soil. However, when the minimum $Z_{F}$ value is around 0.59 for the wettable sandy loam, the water quality indicators have seriously exceeded the agricultural irrigation water quality standards in China, and it is not suitable for irrigation. Therefore, in the irrigation of wettable sandy loam with sewage, it is necessary to consider the impact of crop growth, environment, and long-term 
irrigation on soil water repellency rather than simply consider its influence on infiltration characteristics.

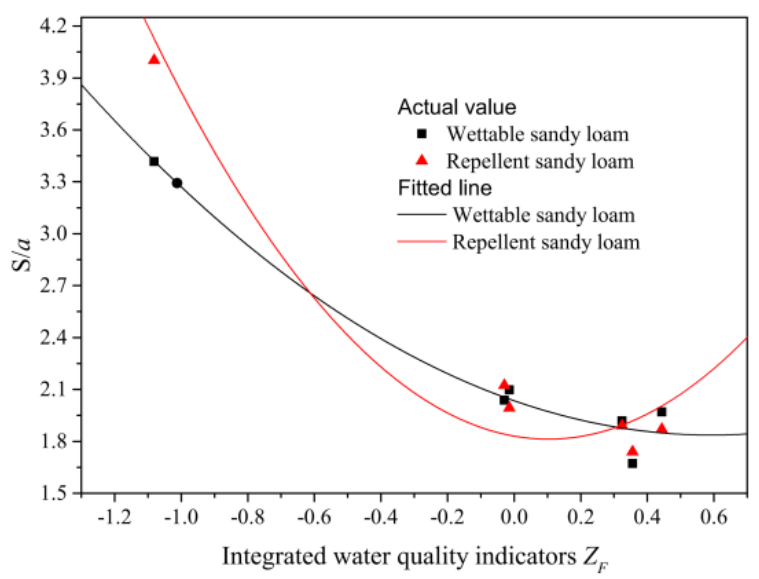

Figure 6. Relationship between S/a (the ratio of sorptivety to the wetting front coefficient) and comprehensive water quality index $Z_{F}$

\section{Conclusions}

Infiltration experiments were conducted on a wettable and a water repellent sandy loam with TWW to determine the water quality index and analyze the effect of water quality on wetting front and cumulative infiltration volume.

(1) The water quality has a great effect on the cumulative infiltration and wetting front of wettable sandy loam. The greater the comprehensive water quality index is, the greater the cumulative infiltration volume and wetting front are. But the water quality has a great effect on the cumulative infiltration but no effect on wetting front of repellency soil. Soil water repellency will decrease soil sorptivety $(S)$. There is a power function relation and positive linear correlation between $S$ and COD, $S$ and $Z_{F}$, respectively. Meanwhile a quadratic polynomial relationship exists between the ratio of soil sorptivety $S$ to the wetting front coefficient $a$ and the comprehensive water quality index, and there is a minimum value in the curve.

(2) When both cumulative infiltration and wetting front requirements in TWW irrigation are taken into consideration, COD and $Z_{F}$ should be less than $170 \mathrm{mg} / \mathrm{L}$ and 0.59 , respectively, in wettable sandy loam while the two values should be less than $140 \mathrm{mg} / \mathrm{L}$ and 0.10 , respectively, in repellency sandy loam. However, the study of this paper is relatively macroscopic, the changes in the microstructure between the reclaimed water and the soil pores need to be studied. When the soil water content is same, as the contact angle increases, the matrix suction will continue to decrease, making the soil infiltration rate slow down. Analyzing the relationship between the contact angle and the microstructure of soil pores during soil infiltration is a future research direction.

Acknowledgements. This work was supported by the National Natural Science Foundation of China (51409221, 51979234) and Basic Research Business Fee of Northwest A\&F University (2452017116) and Humanities and Social Science Program of Northwest A\&F University (Z109021405) and National Key R\&D Program of China (2017YFC0403503). 


\section{REFERENCES}

[1] Balks, M. R., Bond, W. J., Smith, C. J. (1998): Effects of sodium accumulation on soil physical properties under an effluent-irrigated plantation. - Australian Journal of Soil Research 36: 821-830.

[2] Bedbabis, S., Rouina, B. B., Boukhris, M., Ferrara, G. (2014): Effect of irrigation with treated wastewater on soil chemical properties and infiltration rate. - Journal of Environmental Management 133: 45-50.

[3] Bisdom, E. B. A., Dekker, L. W., Schoute, J. F. T. (1993): Water repellency of sieve fractions from sandy soils and relationships with organic material and soil structure. Geoderma 24-28: 105-118.

[4] Bond, R. D. (1964): The influence of the microflora on the physical properties of soils. II . field studies on water repellent sands. - Australian Journal of Soil Research 2(1): 123-131.

[5] Bughici, T., Wallach, R. (2016): Formation of soil-water repellency in olive orchards and its influence on infiltration pattern. - Geoderma 262: 1-11.

[6] Carrillo, M. L. K., Letey, J., Yates, S. R. (2000): Unstable Water Flow in a Layered Soil: II. Effects of an Unstable Water-Repellent Layer. - Soil Science Society of America Journal 64: 456-459.

[7] Chaney, K., Swift, R. S. (1986): Studies on aggregate stability. II .The effect of humic substances on the stability of re-formed soil aggregates. - Journal of Soil Science 37(2): 337-343.

[8] Chau, H. W., Goh, Y. K., Vujanovic, V., Si, B. C. (2012): Wetting properties of fungi mycelium alter soil infiltration and soil water repellency in a $\gamma$-sterilized wettable and repellent soil. - Fungal Biology 116(12): 1212-1218.

[9] Chen, X. H., Song, J. X., Cheng, C., Wang, D. M., Lackey, S. O. (2009): A new method for mapping variability in vertical seepage flux in streambeds. - Hydrogeology Journal 17(3): 519-525.

[10] Chen, J., Zhang, Z., Gillerman, L., Wang, Z. (2013): Analysis of principal components of wastewater affecting soil water repellency. - Journal of Drainage and Irrigation Machinery Engineering 31(5): 434-439.

[11] DeBano, L. F. (1981): Water repellent soils: a state-of-the-art. - United States Department of Agriculture Forest Service General Technical Report PSW-46.

[12] DeBano, L. F. (2000): Water repellency in soils: A historical overview. - Journal of Hydrology 231-232: 4-32.

[13] Dekker, L. W., Jungerius, P. D. (1990): Water repellency in the dunes with special reference to the Netherlands. - Dunes of the European coasts 18: 173-183.

[14] Dekker, L., Ritsema, C. J. (2000): Wetting patterns and moisture variability in water repellent Dutch soils. - Journal of Hydrology 231-232: 148-164.

[15] Dekker, L. W., Ritsema, C. J., Oostindie, K., Wesseling, J. G., Geissen, V. (2018): Effects of a soil surfactant on grass performance and soil wetting of a fairway prone to water repellency. - Geoderma: 10.1016/j.geoderma.2018.09.016.

[16] Durgin, P. B., Chaney, J. G. (1984): Dispersion of Kaolinite By Dissolved Organic Matter From Douglas-Fir Roots. - Canadian Journal of Soil Science 64: 445-455.

[17] Fortun, A., Fortun, C., Ortega, C. (1989): Effect of farmyard manure and its humic fractions on the aggregate stability of a sandy-loam soil. - Journal of Soil Science 40(2): 293-298.

[18] Frenkel, H., Levy, G. J., Fey, M. V. (1992): Organic and Inorganic Anion Effects on Reference and Soil Clay Critical Flocculation Concentration. - Soil Science Society of America Journal 56(6): 1762-1766.

[19] Halliwell, D. J., Barlow, K., Nash, D. (2001): A review of the effects of wastewater sodium on soil physical properties and their implications for irrigation systems. Australian Journal of Soil Research 39(6): 1259-1267. 
[20] Jex, G. W., Bleakley, B. H., Hubbell, D. H., Munro, L. L. (1985): High Humidityinduced Increase in Water Repellency in Some Sandy Soils. - Soil Science Society of America Journal 49(5): 1177-1182.

[21] Jiménez-Pinilla, P., Lozano, E., Mataix-Solera, J., Arcenegui, V., Jordán, A., Zavala, L. M. (2016): Temporal changes in soil water repellency after a forest fire in a Mediterranean calcareous soil: Influence of ash and different vegetation type. - Science of the Total Environment 572: 1252-1260.

[22] Jordán, A., Zavala, L. M., Nava, A. L., Alanís, N. (2009): Occurrence and hydrological effects of water repellency in different soil and land use types in Mexican volcanic highlands. - Catena 79(1): 60-71.

[23] King, P. M. (1981): Comparison of methods for measuring severity of water repellence of sandy soils and assessment of some factors that affect its measurement. - Australian Journal of Soil Research 19: 275-285.

[24] Lado, M., Ben-Hur, M. (2009): Treated domestic sewage irrigation effects on soil hydraulic properties in arid and semiarid zones: A review. - Soil and Tillage Research 106(1): 152-163.

[25] Letey, J. (1969): Measurement of contact angle, water drop penetration time and critical surface tension. - Symposium on Water Repellent soils, May 6-10, Univ. of California.

[26] Leuther, F., Weller, U., Wallach, R., Vogel, H-J. (2018): Quantitative analysis of wetting front instabilities in soil caused by treated waste water irrigation. - Geoderma 319: 132141.

[27] Levy, G. J., Rosenthal, A., Tarchitzky, J., Shainberg, I., Chen, Y. (1999): Soil hydraulic conductivity changes caused by irrigation with reclaimed waste water. - Journal of Environmental Quality 28(5): 1658-1664.

[28] Li, Y., Wang, X. F., Cao, Z. K., Si, B. C. (2017): Water repellency characteristic curve influenced by drying and wetting processesSoil. - Canadian Journal of Soil Science 97(2): 226-240.

[29] Liu, Z., Rahav, M., Wallach, R. (2019): Spatial variation of soil water repellency in a commercial orchard irrigated with treated wastewater. - Geoderma 333(7): 214-224.

[30] Mataix-Solera, J., García-Irles, L., Morugán, A., Doerr, S. H., Garcia-Orenes, F., Arcenegui, V., Atanassova, I. (2011): Longevity of soil water repellency in a former wastewater disposal tree stand and potential amelioration. - Geoderma 165(1): 78-83.

[31] McGhie, D. A., Posnerk, A. M. (1980): Water repellence of a heavy-textured Western Australian surface soil. - Australian Journal of Soil Research 18(3): 309-323.

[32] Misaghi, F., Delgosha, F., Razzaghmanesh, M., Myers, B. (2017): Introducing a Water Quality Index for Assessing Water for Irrigation Purposes: A Case Study of the Ghezel Ozan River. - Science of the Total Environment 589(C): 107-116.

[33] Morales, V. L., Parlange, J. Y., Steenhuis, T. S. (2010): Are preferential flow paths perpetuated by microbial activity in the soil matrix? A review. - Journal of Hydrology 393(1-2): 29-36.

[34] Nadav, I., Arye, G., Tarchitzky, J., Chen, Y. (2012): Enhanced infiltration regime for treated-wastewater purification in soil aquifer treatment (SAT). - Journal of Hydrology 420-421: 275-283.

[35] Nadav, I., Tarchitzky, J., Chen, Y. (2012): Soil cultivation for enhanced wastewater infiltration in soil aquifer treatment (SAT). - Journal of Hydrology 470-471: 75-81.

[36] Philip, J. R. (1957): The theory of infiltration: 4. Sorptivity and algebraic infiltration equations. - Soil Science 84: 257-264.

[37] Piccolo, A., Pietramellara, G., Mbagwu, J. S. C. (1997): Use of humic substances as soil conditioners to increase aggregate stability. - Geoderma 75(32): 267-277.

[38] Rye, C. F., Smettem, K. R. J. (2017): The effect of water repellent soil surface layers on preferential flow and bare soil evaporation. - Geoderma 289: 142-149. 
[39] Shakesby, R. A., Coelho, C. D. A., Ferreira, A. D., Terry, J. P., Walsh, R. P. D. (1993): Wildfire impacts on soil erosion and hydrology in wet mediterranean forest, Portugal. International Journal of Wildland Fire 3(2): 95-110.

[40] Shakesby, R. A., Doerr, S. H. (2006): Wildfire as a hydrological and geomorphological agent. - Soil Science Society of America Journal 74: 269-307.

[41] Sheng, F., Wu, D., Zhang, L. (2016): Review on effect of reclaimed water irrigation on soil water movement in cropland. - Transactions of the Chinese Society of Agricultural Engineering 32: 46-51.

[42] Singh, B., Sihag, P., Singh, K. (2017): Modelling of impact of water quality on infiltration rate of soil by random forest regression. - Modeling Earth Systems and Environment 3: 999-1004.

[43] Stenstrom, T. A. (1989): Bacterial Hydrophobicity, an Overall Parameter for the Measurement of Adhesion Potential to Soil Particles. - Microbiology 55(1): 142-147.

[44] Travis, M. J., Weisbrod, N., Gross, A. (2008): Accumulation of oil and grease in soils irrigated with greywater and their potential role in soil water repellency. - Science of the Total Environment 394(1): 68-74.

[45] Vinten, A. J. A., Mingelgrin, U., Yaron, B. (1983): The effect of suspended solids in wastewater on soil hydraulic conductivity: II. vertical distribution of suspended solids. Soil Science Society of America Journal 47(686): 408-412.

[46] Vries, D. J. (1972): Soil filtration of wastewater effluent and the mechanism of pore clogging. - Journal of the Water Pollution Control Federation 44: 565-573.

[47] Wallach, R., Ben-Arie, O., Graber, E. R. (2005): Soil Water Repellency Induced By Long-Term Irrigation with Treated Sewage Effluent. - Journal of Environment Quality 34(5): 1910-20.

[48] Wallach, R., Jortzick, C. (2008): Unstable finger-like flow in water-repellent soils during wetting and redistribution - The case of a point water source. - Journal of Hydrology 351(1-2): 26-41.

[49] Wallach, R. (2010): Effect of soil water repellency on moisture distribution from a subsurface point source. - Water Resources Research 46(8): 1-9. 